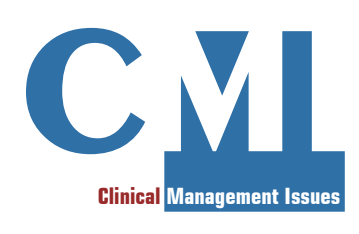

\title{
Gender-related differences in dietary habits
}

\section{INTRODUCTION}

The term "gender" indicates the characteristics of women and men that can be considered socially determined as they are strongly influenced by psychosocial and cultural factors. The term "sex" refers, instead, to the biological features that are determined by the different physiology characterizing women and men. In other words, we born female or male but become women and men during the time by learning and adopting different behaviors that identify all together the own gender role. It should be underlined that the gender behaviors are defined by the sociocultural environment, so that a defined behavior might be considered in different way, i.e. masculine or feminine, depending on the cultural expectations [1].

\section{SEX- AND \\ GENDER-DETERMINANTS OF NON-COMMUNICABLE DISEASES (NCDS) DEVELOPMENT}

A number of epidemiological and clinical studies strongly support the evidence that lifestyle represents a main determinant of health. In particular, inadequate diet together with low level of physical activity are considered main determinants in the onset of chronic-degenerative diseases (defined as non-communicable diseases, NCDs), such as cardiovascular diseases, type 2 diabetes, and cancer. Consequently, they are reported as "lifestyle-related" diseases to highlight the relevance of individual behaviors as preventive tool $[2,3]$. Notably, lifestyle, as every behavior, results from the combination of familiar, economic, educational, and social factors [4] that, in turn, are heavily influenced by gender differences [5]. However, it should also be pointed out that each individual responds to nutrients in a different way on the basis of genetic background, hormonal levels, metabolic rate, etc. [6-9]. Actually, the European Commission has evidenced the need to combine the knowledge on sex-driven response to nutrients with that on gender-related dietary choices in order to design tailored preventive interventions aimed at effectively promoting healthy lifestyles [10].

\section{SEX- AND GENDER-RELATED DIFFERENCES IN FAT STORAGE AND OBESITY RATES}

Obesity is one of the major public health concerns as it is one of the major risk factors for NCDs since all of them share low-grade inflammatory status as hallmark [11]. Obesity is characterized by a pathologic increase of fat storage into the adipose tissue. The fat
Center for GenderSpecific Medicine, Italian National Institute of Health
Corresponding author Roberta Masella Senior researcher, Nutrition Unit Center for Gender-specific Medicine, Italian National Institute of Health, Viale Regina Elena 299, 00161 Rome, Italy Tel. +390649902544 Fax +390649902763 roberta.masella@iss.it

Disclosure

The authors declare they have no competing financial interests

concerning the topics of this article 
mass expansion is critical, because it leads to adipocyte dysfunctions, that can trigger a number of alterations in the metabolic and immune performance [12-14].

The fat mass expansions are determined not only by an imbalance between energy intake and energy expenditure but, also, by the dietary habits and the quality of food choices. Therefore, useful predictive tools for obesity, especially in childhood, are both inadequate diet and insufficient physical activity [15].

Scientific evidence demonstrates that women and men greatly differ in lipid metabolism most likely depending on sexual hormones [16]. It is well known that the two sexes are shaped differently. In men, fat depots occupy especially the abdominal district of the body and this fat is called visceral fat (apple shape), whereas in women fat accumulates mainly on the hips and thighs and especially in the subcutaneous tissue (pear shape). Very interestingly, only the visceral fat is positively correlated with the onset of type 2 diabetes, metabolic syndrome, cardiovascular diseases, and some types of cancer [17]. Thus, men with elevated body mass in$\operatorname{dex}(\mathrm{BMI})$ values may show an increased risk of chronic diseases with respect to women having comparable BMI. However, women are at greater risk of obesity, as demonstrated by the worldwide prevalence of obesity, which is more frequent in women than in men [18]. It should be highlighted, however, that relevant differences in the prevalence of obesity exist when age and geographical, social, and economic conditions are considered [18]. The cause of this difference between sexes is not clear yet and strongly depends on environmental and cultural aspects. A study carried out in South Africa [19] suggested two factors potentially responsible for the gender difference in obesity rates; the first one could be food deprivation during childhood, because it is quite common that male children receive better feeding than females; and the second one might depend on the higher socio-economic status, as in some cultural environment richness is associated with chubbiness. Probably, these issues can not be applied to highly industrialized countries.

On the other hand, the Italian behavioral risk factor surveillance system - PASSI (Progressi delle Aziende Sanitarie per la Salute in Italia) reported that the consumption of vegetables and fruit as well as the level of physical activity, that are main determinants of obesity and overweight onset, show significant differences between males and females [20,21]. In addition, they are greatly influenced by socio-economic factors, being inversely correlated with the salaries and the level of education [22].

\section{GENDER INFLUENCES DIETARY HABITS}

It should be pointed up that most of the studies aimed at evaluating dietary habits have been carried out in US and Europe and the collected data cannot be extrapolated to other countries, which are geographically and culturally very different from the Western ones.

Unfortunately, unhealthy dietary habits, such as not consuming the recommended five or more servings of fruit and vegetables every day, consuming little milk and dairy products, skipping meals and frequently eating energy-dense nutrient-poor fast- and ready-to-eat foods, are quite common especially among youngsters $[23,24]$. However, the two genders show significant differences regarding dietary intakes and eating behaviors [25]. Women consume more fruit and vegetable, legumes, and whole food, but also more sweets and cakes, with respect to men. Men tend to have food richer in fats and proteins, to drink more wine, beer, spirits, and sweet carbonated drinks; in general they show dietary behaviors potentially favoring overweight and obesity. Students in a U.S. college show significant differences in their weight depending on gender (being the percentage of overweight/obese males higher than females) that mirrors significant differences in the diet consumed [26]. Furthermore, these data provide also interesting evidence about the influence of high socio-economic and cultural levels, such as that of U.S. universities, on food choices. These might be influenced by cultural and advertising pressures promoting, for example, thinness as a criterion for beauty. Data collected in Italy among adult subjects show that, in comparison with men, a higher percentage of women consume daily the recommended five portions of fruit and vegetables. Another aspect that might influence dietary habits is the motivation to adopt healthy eating behaviors [27]. In this regard, an Italian study reported that among type 2 diabetes patients, females seemed to be more willing to follow dietary 
advice than men. Actually, women appear to be especially aware of the role exerted by nutrition on human health, and thus more ready to adopt a healthier diet. Moreover, women are particularly worried about their own body image, of which they are generally unsatisfied [28]. Nevertheless, women have been demonstrated to give up and abandon the new dietary plan more frequently than men. A possible explanation is that the good results obtained by moving toward healthier dietary habits are much more pronounced in men than in women that, thus, might be easily discouraged.

Finally, it should be considered that a number of gender-based stereotypes about food exist in every human culture. In extreme synthesis, meats rich of fat and protein are food for men, whereas a little mixed salad is food for women. Although the causes for this are far from being fully elucidated, the consequence on food choice and dietary habits might be relevant because both men and women tend to adhere to those expectations most likely for reinforcing their own gender identity $[29,30]$.

\section{CONCLUSIONS}

Non-communicable diseases, that taken all together represent the first cause of death worldwide, are greatly influenced by individual behavior as regards, in particular, dietary habits and physical activity. These factors are both greatly influenced by gender, which is, consequently, a main determinant of human health. On the other hand, sex might significantly affect metabolism and the individual response to food intake. On this basis, it is clear that all these aspects should be considered in order to move toward more personalized nutritional advice and for effective promotion of healthy behaviors.

\section{REFERENCES}

1. MahalikJR, Locke BD, Ludlow LH, et al. Development of the conformity to masculine norms inventory. Psychol Men Masc 2003; 3: 25; https://doi.org/10.1037/1524-9220.4.1.3

2. Mastrangelo A, Barbas C. Chronic diseases and lifestyle biomarkers identification by metabolomics. Adv Exp Med Biol 2017; 965: 235-63; https://doi.org/10.1007/978-3-31947656-8_10

3. Passi SJ. Prevention of non-communicable diseases by balanced nutrition: population-specific effective public health approaches in developing countries. Curr Diabetes Rev 2016 Sep 5 [Epub ahead of print]

4. Mayén AL, de Mestral C, Zamora G, et al. Interventions promoting healthy eating as a tool for reducing social inequalities in diet in low- and middle-income countries: a systematic review. Int J Equity Health 2016; 15: 205; https://doi.org/10.1186/s12939-016-0489-3

5. Hunt $\mathrm{K}$, Lewars $\mathrm{H}$, Emslie $\mathrm{C}$, et al. Decreased risk of death from coronary heart disease amongst men with higher 'femininity' scores: a general population cohort study. Int J Epidemiol 2007; 36: 612-20; https://doi.org/10.1093/ije/dym022

6. Caslake MJ,Miles EA, Kofler BM, et al. Effect of sex and genotype on cardiovascular biomarker response to fish oils: the FINGEN Study. Am J Clin Nutr 2008; 88: 618-29

7. Charchar FJ, Bloomer LD, Barnes TA, et al. Inheritance of coronary artery disease in men: an analysis of the role of the Y chromosome. Lancet 2012; 379: 915-22; https://doi.org/10.1016/ S0140-6736(11)61453-0

8. Ordovas JM, Corella D, Cupples LA, et al. Polyunsaturated fatty acids modulate the effects of the APOA1 G-A polymorphism on HDL-cholesterol concentrations in a sex-specific manner: the Framingham Study. Am J Clin Nutr 2002; 75: 38-46

9. Phillips CM, Goumidi L, Bertrais S, et al. Gene-nutrient interactions and gender may modulate the association between ApoA1 and ApoB gene polymorphisms and metabolic syndrome risk. Atherosclerosis 2011; 214: 408-14; https://doi.org/10.1016/j.atherosclerosis.2010.10.029

10. World Health Organization. Integrating Gender Perspectives in the work of WHO-WHO Gender Policy. Geneva: World Health Organization, 2002. Available at http://apps.who.int/ iris/handle/10665/67649 (last accessed June 2017)

11. Hotamisligil GS. Inflammation and metabolic disorders. Nature 2006; 444: 860-7; https://doi. org/10.1038/nature05485 
12. Khandekar MJ, Cohen P, Spiegelman BM. Molecular mechanisms of cancer development in obesity. Nat Rev Cancer 2011; 11: 886-95; https://doi.org/10.1038/nrc3174

13. Rask-Madsen C, Kahn CR. Tissue-specific insulin signaling, metabolic syndrome, and cardiovascular disease. Arterioscler Thromb Vasc Biol 2012; 32: 2052-9; https://doi.org/10.1161/ ATVBAHA.111.241919

14. Vandanmagsar B, Youm YH, Ravussin A, et al. The NLRP3 inflammasome instigates obesity-induced inflammation and insulin resistance. Nat Med 2011; 17: 179-88; https://doi. org/10.1038/nm.2279

15. Perry CP, Keane E, Layte R, et al. The use of a dietary quality score as a predictor of childhood overweight and obesity. BMC Public Health 2015; 15: 581; https://doi.org/10.1186/s12889015-1907-y

16. Santosa S, Jensen MD. The sexual dimorphism of lipid kinetics in humans. Front Endocrinol (Lausanne) 2015; 6: 103; https://doi.org/10.3389/fendo.2015.00103

17. Britton KA, Massaro JM, Murabito JM, et al. Body fat distribution, incident cardiovascular disease, cancer, and all-cause mortality. J Am Coll Cardiol 2013; 62: 921-5; https://doi. org/10.1016/j.jacc.2013.06.027

18. World Health Organization. Obesity. Health topics. Geneva: World Health Organization. Available at http://www.who.int/topics/obesity/en/ (last accessed June 2017)

19. Case A, Menendez A. Sex differences in obesity rates in poor countries: evidence from South Africa. Econ Hum Biol 2009; 7: 271-82; https://doi.org/10.1016/j.ehb.2009.07.002

20. Centro Nazionale di Epidemiologia, Sorveglianza e Promozione della Salute. Epicentro. La sorveglianza PASSI. Consumo frutta e verdura. Roma: Istituto Superiore di Sanità. Available at http://www.epicentro.iss.it/passi/dati/frutta.asp (last accessed June 2017)

21. Centro Nazionale di Epidemiologia, Sorveglianza e Promozione della Salute. Epicentro. La sorveglianza PASSI. Attività fisica. Roma: Istituto Superiore di Sanità. Available at http://www. epicentro.iss.it/passi/dati/attivita.asp (last accessed June 2017)

22. Centro Nazionale di Epidemiologia, Sorveglianza e Promozione della Salute. Epicentro. La sorveglianza PASSI. Sovrappeso e obesità. Roma: Istituto Superiore di Sanità. Available at http://www.epicentro.iss.it/passi/dati/sovrappeso.asp (last accessed June 2017)

23. Lowry R, Galuska DA, Fulton JE, et al. Physical activity, food choice, and weight management goals and practices among US college students. Am J Prev Med 2000; 18: 18-27; https://doi. org/10.1016/S0749-3797(99)00107-5

24. Malinauskas BM, Raedeke TD, Aeby VG, et al. Dieting practices, weight perceptions, and body composition: a comparison of normal weight, overweight, and obese college females. Nutr J 2006; 5: 11; https://doi.org/10.1186/1475-2891-5-11

25. Li KK, Concepcion RY, Lee H, et al. An examination of sex differences in relation to the eating habits and nutrient intakes of university students. JNutr Educ Behav 2012; 44: 246-50; https:// doi.org/10.1016/j.jneb.2010.10.002

26. Yahia N, Wang D, Rapley M, et al. Assessment of weight status, dietary habits and beliefs, physical activity, and nutritional knowledge among university students. Perspect Public Health 2016; 136: 231-44; https://doi.org/10.1177/1757913915609945

27. Leblanc V, Begin C, Corneau L, et al. Gender differences in dietary intakes: what is the contribution of motivational variables? J Hum Nutr Diet 2015; 28: 37-46; https://doi. org/10.1111/jhn.12213

28. Ferguson CJ, Winegard B, Winegard BM. Who is the fairest one of all? How evolution guides peer and media influences on female body dissatisfaction. Rev Gen Psychol 2011; 15: 11-28; https://doi.org/10.1037/a0022607

29. Cavazza N, Guidetti M, Butera F. Ingredients of gender-based stereotypes about food. Indirect influence of food type, portion size and presentation on gendered intentions to eat. Appetite 2015; 91: 266-72; https://doi.org/10.1016/j.appet.2015.04.068

30. Cavazza N, Guidetti M, Butera F. Portion size tells who I am, food type tells who you are: Specific functions of amount and type of food in same- and opposite-sex dyadic eating contexts. Appetite 2017; 112: 96-101; https://doi.org/10.1016/j.appet.2017.01.019 